\title{
Induction of laccase in fungus, Cyathus stercoreus using some aromatic inducers
}

\author{
Bhuvnesh Yadav \\ University, Gurugram, Haryana, INDIA \\ E-mail: bhuvneshyadav@gmail.com \\ Received: July 31, 2017; Revised received: December 7, 2017; Accepted: February 20, 2018
}

Department of Chemistry, Biochemistry and Forensic Science, Amity School of Applied Science, Amity

\begin{abstract}
To improve the feed quality removal of lignin from plant biomass is essential. To improve the activity of laccase of white rot fungi, aromatic inducers are used. In this study three inducers [Resorcinol (5mM and 10mM), Xylidine and Anisaldehyde] to induce the production of laccase enzyme in the culture of fungus: Cyathus stercoreus. Resorcinol $(10 \mathrm{mM})$ was found to be the best inducer among the rest. The enzyme activity was observed highest on the $8^{\text {th }}$ day of induction $(226.7 \mathrm{U} / \mathrm{ml})$. Protein content was also increased with the age of the culture. $80 \%$ ammonium sulphate was suitable for precipitating the laccase enzyme for culture filtrate. The laccase production can be enhanced with inducers and can be further used for the removal of lignin from the plant biomass.
\end{abstract}

Keywords: Cyathus stercoreus, Enzyme, Fungus, Lignin

\section{INTRODUCTION}

The polysaccharides in lignified plant cell wall are abundant and constitute potential economic renewable resources of sugars of live-stock as feed. Before one focuses on the utilization of renewable sources (lignocelluloses), it is necessary to know about the factors that hinder their fullest usage (Chapple et al., 2007). The most important among these are low digestibility and protein content, poor palatability and high lignin content which make such resources in adequate as a sole source of feed (Patel et al., 2009). It has been found that the agricultural biomass (lignocelluliosic) comparises of 10-25\% lignin (Anwar et al., 2014). However, the continuous interest of scientists is helping in improving the feed quality of the crop residues on account of easy availability and nutrients status. As per Ministry of Renewable energy, India has over 5,940 MW biomass based power plants (MNRE Annual Report 2015-16), but pretreating lignocellulosic biomass is an energy and time consuming process (Mulakhudair et al., 2017).

The environmentally benign way to accomplish the removal of lignin in plant matter is to harness the lignin degrading capabilities of the microorganism (Falade et al., 2016). White rot fungi (Basidiomycetes) is capable of degradation of lignin in addition to the cellulose which is a major component of the wood (Dashtban et al., 2010). This process is catalysed by Lignolytic enzymes catalyse the process by cleaving oxidatively aromatic rings in lignin structure. Manga- nese peroxidase and laccase (E.C.1.10.3.2) of white rot fungi are most important among the lignolytic enzymes (Kunjadia et al., 2016). In addition, they are able to degrade xenobiotic aromatic polymers, persisting as environmental pollutants. Aromatic components have been often discussed as being inducers, enhancers and mediators of their lignolytic enzymes. It is known that supplementing the growth medium with either $\mathrm{Mn}^{2+}$, vertyl alcohol or coal derived humic acid leads to significantly enhanced extracellular lignolytic activities. Aromatic compounds are the inducers of the laccase (Elisashvili et al., 2010). This study was conducted to find out the impact of Resorcinol, anisaldehyde and xylidine as inducers on laccase production.

\section{MATERIALS AND METHODS}

Three different inducers which include Resorcinol in two different concentrations, Xylidine and Anisaldehyde, were used in the experiment. They induced the production of laccase enzyme in the culture of fungus: Cyathus stercoreus. To relate the amount of expressed enzyme was measured by the polyacrylamide gel electrophoresis (PAGE) by comparing the banding patterns of differently induced cultures for the production of laccase.

The fungus: Cyathus stereoreus was cultured and maintained on the malt extract medium. The malt extract broth (ME) was prepared with Malt extract (20gm), Dextrose (20gm) and Peptone (6gm) in 1lt water. The broth was divided into 10 flasks $(50 \mathrm{ml})$ and added three inducers in appropriate amounts and 
labelled as under and autoclaved:

ME control (2 flasks)

$\mathrm{ME}+12$ microliter Anisaldehyde

ME+ $10 \mathrm{mM}$ Xylidine

$\mathrm{ME}+5 \mathrm{mM}$ Resorcinol

$\mathrm{ME}+10 \mathrm{mM}$ Resorcinol

The fungal strains $(15 \mathrm{~mm})$ were inoculated to flasks and incubated at $30^{\circ} \mathrm{C}$ in BOD incubator. The strains with these inducers were observed for Laccase enzyme concentration and protein assay from fourth day of incubation.

Enzyme assay: $400 \mathrm{ml}$ of the samples were taken out in the test tubes, $1.6 \mathrm{ml}$ Guaiacol citrate phosphate buffer was added in each tube followed by $1 / 2$ hour incubation and then the optical density was measured at $470 \mathrm{~nm}$. The optical density was plotted on the graph against the concentration of the sample (Bains et al., 2003).

Protein Assay was done by the Lowry's method (Wilson and Walker, 2000). The partial purification of the laccase was done by $80 \%\left(\mathrm{NH}_{4}\right)_{2} \mathrm{SO}_{4}$, overnight at $4^{\circ} \mathrm{C}$ and centrifugation. To concentrate the protein, dialysis was done, and then the sample was used to perform Sodium dodecyl sulphate- poly acrylamide gel electrophoresis (SDS-PAGE). Two types of gels stacking and resolving gel were used. The coomassie blue staining was done, and bands were observed.

\section{RESULTS AND DISCUSSION}

The results were compared for the production of laccase with different inducers (Resorcinol $(5 \mathrm{mM}$, $10 \mathrm{mM})$, Anisaldehyde, Xylidine). It was found that Resorcinol $(10 \mathrm{mM})$ was found to be the best inducer among them. The enzyme production was highest on the $8^{\text {th }}$ day of induction $(226.7 \mathrm{U} / \mathrm{ml}$ ) (Figure 1). SDSPAGE also confirmed the same results. Protein content also increased to different levels when different inducers were checked for total protein using Lowry's method (Wilson and Walker, 2000). 80\% Ammonium sulphate concentration was suitable for precipitating the enzyme for culture filtrate.

Induction to the various levels by the inducers showed that the production of laccase could be increased by choosing the right inducers. The enzyme activity started on the fourth day and increased till $8^{\text {th }}$ day (2.488U). Protein content was also increased with the age of the culture.

Enzymatic degradation of the dyes, bioremediation of toxic chemicals, pre-treatment of biological substances and delignification has increased the essence of biological catalysts. Laccase has emerged as a valuable enzyme as it is successfully used in delignification (Sharma et al., 2005), dye degradation (Mendoza et al., 2011), bioremediation of toxic chemical wastes (Mayer and Staples, 2002), and pre-treatment of biomass for the production of biofuel (Placido and Capareda, 2015). Solid state fermentation (SSF) has en-

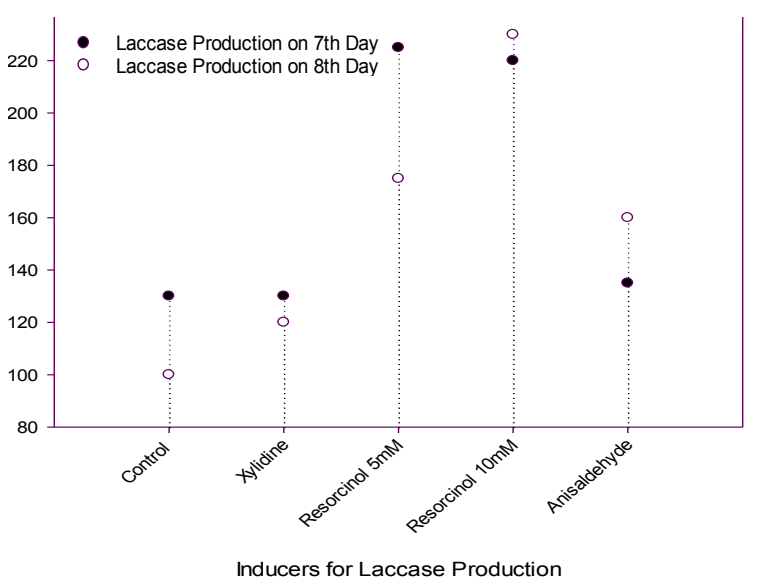

Fig. 1. Laccase production (in $\mathrm{U} / \mathrm{ml}$ ) with different inducers at different time intervals.

hanced the production of enzymes and other economically potential products with low capital costs, reduced energy requirement, and simple fermentation substrate/ media (Kapoor et al., 2000). The activity enhancement with aromatic compounds was tested, and no effect was observed on enzyme secretion by Ganoderma lucidum in mannitol-containing medium (Elisashvili, 2010). Impact of phenanthrene, fluoranthene, pyrene, and chrysene, fluorene and anthrecene were observed by Pozdniakova et al. (Pozdniakova et al., 2011) and it was observed that except fluorene and anthrecene, others were actively inducing the enzyme.

A few studies have shown that there was production enhancement by the addition of phenolic and nonphenolic inducers. The maximum production was observed on the $12^{\text {th }}$ day with a further decline in the production after day 15 with ST02 strain (Patel and Gupte 2016). Mazumder et al. (Mazumder et al., 2009) observed that Pleurotus ostreatus have strong proteolytic activity in submerged fermentation $(\mathrm{SmF})$ presumably caused subsequent laccase degradation, which lowered the ultimate laccase production in $\mathrm{SmF}$ compared to SSF. It has been observed in the previous studies that the lignocellulosic substrate under solid state fermentation is very important for the efficient and costeffective production of the ligninolytic enzymes. Different lignocellulosic substrates like wheat straw, wheat bran, rice straw, and rice bran were screened for the production of laccase (Patel and Gupte, 2016). In addition to the smF of wheat bran, the structure and the concentration of aromatic compounds play an important role in the regulation of enzyme synthesis.

\section{Conclusion}

In a comparative analysis of the inducers [Resorcinol (5mM and $10 \mathrm{mM})$, Xylidine and Anisaldehyde] for the production of lignolytic enzymes, Resorcinol (10mM) was found to be the best inducer among the rest. The increase in enzyme activity and protein content was 
observed with the aging of culture. The laccase enzyme with Resorcinol $(10 \mathrm{mM})$ as inducer can be utilised for the removal of lignin from the plant biomass.

\section{REFERENCES}

Anwar, Z., Gulfraz, M., Irshad, M. (2014). Agro-industrial lignocellulosic biomass a key to unlock the future bioenergy: A brief review. J. Rad. Res.Appl. Sc. 7(2):163173.

Bains, J., Capalash, N., Sharma, P. (2003). Laccase from a non-melanogenic, alkalotolerant $\gamma$-proteobacterium JB isolated from industrial wastewater drained soil. Biotechnol Lett. 25(1):155-1159. doi: 10.1023/ A:1024569722413.

Chapple, C., Ladisch, M., Meilan, R. (2007). Loosening lignin's grip on biofuel production. Nat. Biotechnol. 25: 746-748.

Dashtban, M., Schraft, H., Syed, T.A., Qin, W. (2010). Fungal biodegradation and enzymatic modification of lignin. Int. J Biochem. Mol. Biol. 1(1):36:50.

Elisashvili, V., Kachlishvili, E., Khardziani, T., Agathos, S.N. (2010). Effect of aromatic compounds on the production of laccase and manganese peroxidase by whiterot basidiomycetes. J Ind. Microbiol. Biotechnol. 37 (10):1091-1096. doi: 10.1007/s10295-010-0757-y. Epub 2010 Jun 9.

Falade, A.O., Nwodo, U.U., Iweriebor, B.C., Green, E., Mabinya, L.V., Okoh, A.I. (2016). Lignin peroxidase functionalities and prospective applications. Microbio. Open. 6(1):e000394

Kunjadia, P.D., Sanghvi, G.V., Kunjadia, A.P., Mukhopadhyay, Dave, G.S., (2016). Role of ligninolytic enzymes of white rot fungi (Pleurotus spp.) grown with azo dyes. Springplus 5(1):1487.

Lowry, O.H., Rosebrough, N.J., Farr, A.L., Randall, R.J. (1951). Protein measurements with Folin-phenol reagent. J Biol. Chem. 193:265-275.

Kapoor, M., Beg, Q.K., Bhushan, B., Dadhich, K.S., Hoondal, G.S. (2000). Production and partial purification and characterization of a thermo-alkali stable poly- galacturonase from Bacillus sp. MG-cp-2. Process Biochem. 36:467-473. doi:10.1016/S0032-9592(00) 00238-7

Mayer, A.M., Staples, R.C. (2002). Laccase: new functions for an old enzyme. Phytochemistry. 60:551-565.

Mazumder, S., Basu, K.S., Mina, M. (2009). Laccase production in solid state and submerged fermentation by Pleurotus ostreatus. Eng. Life Sci. 9: 45-52.

Mendoza, L., Jonstrup, M., Hatti-Kaul, R., Mattiasson, B. (2011). Azo dye decolorization by a laccase/mediator system in a membrane reactor: enzyme and mediator reusability. Enzyme Microb Technol.49:478-84.

Ministry of new and renewable energy, Government of India (2016). MNRE Annual Report 2015-16, Retrieved on 20 November, 2017 from http://biomasspower.gov.in/ About-us-3-Biomass\%20Energy\%20scenario-4.php.

Mulakhudair, A.R., Hanotu, J., Zimmerman, W. (2017). Exploiting ozonolysis-microbe synergy for biomass processing: Application in lignocellulosic biomass pretreatment. Biomass and bioenergy. 105:147-154.

Patel, H., Gupte, A., Gupte, S. (2009). Effect of different culture conditions and inducer on production of laccase by a basidiomycetes fungal isolate Pleurotus ostreatus HP-1. Biores. 4(1):268-284.

Patel, H. and Gupte, A. (2016). Optimization of different culture conditions for enhanced laccase production and its purification from Tricholoma giganteum AGHP. Bioresources and Bioprocessing. 3:11.

Placido, J., Capareda, S.(2015). Ligninolytic enzymes: a biotechnological alternative for bioethanol production. Bioresources and Bioprocessing. 2:23.

Pozdniakova, N.N., Nikiforova, S.V., Makarov, O.E., Turkovskaia, O.V. (2011). Effect of polycyclic aromatic hydrocarbons on laccase production by white rot fungus Pleurotus ostreatus D1. Prikl Biokhim Mikrobiol. 47 (5):595-601.

Sharma, K. K., Kapoor, M., Kuhad, R. C. (2005). In vivo enzymatic digestion, in vitro xylanase digestion, metabolic analogues, surfactants and polyethylene glycol ameliorate laccase production from Ganoderma sp. kk02. Lett. Appl. Microbiol. 41:24-31. doi: 10.1111/j.1472 $-765 X .2005 .01721$.

Wilson, K. and Walker, J. (2000). Practical Biochemistry: Principles and Techniques. Cambridge University Press. 